\title{
The loudness of the "Unsaid": Proverbs in selected African drama
}

\author{
Gbemisola Adeoti \\ Professor \\ Department of English \\ Faculty of Arts \\ Obafemi Awolowo University \\ Ile Ife, Nigeria. \\ Email: remiade@oauife.edu.ng, ayinla8o@yahoo.com
}

\begin{abstract}
Submitted: April 4, 2018 / Accepted: February 25, 2019 / Published: October 4, 2019
\end{abstract}

\begin{abstract}
The paper reflects on the use of proverbs as communicative constituents of African drama, how they are used by playwrights to establish themes, build context, enrich dialogue and develop characterisation. Many African paremiology scholars have studied proverbs as expressions of social realities and cultural practices as well as markers of identities (Amali, 2001; Akinyemi, 2007; Yankah, 2012; and Appiah-Adjei, 2014). The paper observes that in the bid to represent socio-cultural realities on stage, proverbs constitute a significant part of verbal resources in the dialogue of selected African plays. There is, therefore, the need to probe further the use of proverbs in African drama to reveal the "unsaid" elements of discourse and socio-cultural situations couched in proverbs with a view to enriching our understanding of the plays. To this end, textual illustrations are drawn from Soyinka's Death and the King's Horseman, Ola Rotimi's Kurunmi, Ama Ata Aidoo's Anowa and Mohammed ben-Abdallah's The Trial of Mallam Ilya.
\end{abstract}

Keywords: Proverbs, paremiology, African drama, meaning, "Unsaid" 


\section{Introduction}

Proverbs in many cultures across the world are developed in humans' attempt to come to terms with the complexity and dynamism of their existence. Proverbs are indexes of a people's language, history, literature and culture. They are associated with "elders" who are deemed to be wise with age and not expected to speak in "plain" terms. Wolfgang Mieder, a foremost paremiologist, recognises this when he says that proverbs are "the wisdom of ages gone by", though they are also meaningful and relevant in the modern era. They are based on "observations and generalisations about basic human behaviour and the trials and trepidation of human life" (2012:143). In an earlier publication, Meider defines a proverb as a "short, generally known sentence of the folk which contains wisdom, truth, morals and traditional views in a metaphorical, fixed and memorisable form and which is handed down from generation to generation" (1985: 113).

In a similar manner, Kwesi Yankah (2012) sees proverbs not only as locutionary act, but also as products of paradigmatic performance, and they are never fixed in context and content. Using the example of the Akan people of Ghana, he acknowledges proverbs as compact means of preserving tradition through their dynamic re-usage, speakers after speakers; generations after generations. He also notes that each new sociocultural milieu or context affects the performance of proverbs; showing that context wields a considerable influence in paremiology. Interestingly, there is no aspect of life that escapes the sharp eye of the proverbial, whether private or public.

In his seminal study of traditional motifs in making contemporary statements in contemporary African drama, Appiah-Adjei (2014) adopts Sankofa, the archetypal proverbial bird in Akan cosmology. The bird stands for the timeless and limitless value of tradition in interpreting contemporary events and coming to terms with present day realities. He submits that African dramatists are united in their reaching out to traditional motifs, symbols and rhetorical resources in their efforts to produce plays that are topical and relevant to people's socio-political experience in the contemporary era. As part of the traditional motifs, Appiah -Adjei considers the use of proverbs by the playwrights in his analysis of selected Ghanaian plays (such as Efo Kojo Mawugbe's In the Chest of a Woman, Efua Sutherland's Edufa, Martin Owusu's The Legend of Aku Sika and Ama Ata Aidoo's Dilemma of a Ghost). To him, proverbs are: 
Adeoti, G./Legon Journal of the Humanities Vol. 30.1 (2019)

short pithy statements or pieces of traditional wisdom, philosophy, or advice which have passed into general use from generation to generation. They are often expressed in metaphor, rhyme or alliteration, and refer to some common human experience. They are often satirical or mocking in intention. Almost ninety-five percent of traditional proverbs are written in verse. Some of them are contradictory and, in order to better understand them, one should bear in mind that they express the outlook prevailing some centuries ago. (21-22)

The paper is anchored on the paradox of the modern finding explanation for its present reality in the voices of "the ancestors" couched in proverbs. It reflects on the role of proverbs in African drama with a view to understanding the import of the proverbial in representing the challenges of life and living in contemporary Africa. The aim is to put in proper perspective, the role of proverbs as communicative resources deployed by some African dramatists in the building of characterisation and development of conflicts in order to elicit certain emotional responses from the stage and the auditorium. It is our contention that by its very nature, proverbs out-think the unknown well ahead of time and space in depicting human conditions. Indeed, they start out from the particular and reach out to the general in their applications and effects; in contexts and contents. That is why they are often couched in universal and timeless terms. In the textual analysis, attempt is made to lift the veil of complexity to examine ideas underlying proverbs used in the selected plays with a view to enhancing our understanding of their artistic concerns. These plays include Soyinka's Death and the King's Horseman, Ola Rotimi's Kurunmi, Ama Ata Aidoo's Anowa and Mohammed ben-Abdallah's The Trial of Mallam Ilya. A play each is selected from four African dramatists, drawn from Nigeria and Ghana. The two countries, apart from sharing similar experience of British colonialism, also have striking details of similarities in terms of cultural practices among their various ethnic groups.

In contemporary African drama, proverbs are sometimes deployed to communicate across spatial and temporal boundaries. Thus, using the concise, crisp, metaphorical language of the "dead", the "living" pursue a better understanding of their own world and make meaning of their present predicament. Proverbs as instruments of socialisation are used to pass instruction and correct human behaviour. Through warnings encoded in some proverbs, crises in inter-group and interpersonal relationships can be averted while disasters through error of judgment can be avoided. Proverbs reinforce conformity in pursuit of change, while they radiate exciting 
freshness in the toga of the old. Sometimes, proverbs express cross-cultural experience, making them applicable to the whole humanity.

One attribute of a proverb that is of import to us here is its economy of words while making plenty sense like poetry and riddle. According to Ogbeide, a proverb helps to economize words as so much can be said in just one proverb. In his words, "they help to convey delicate and exceptional messages in a rather instructive and innocuous manner" (2013: 18). As a result of its terse and code-like structure, proverb suggests far more than what it actually bears in words and images when it comes to deciphering meaning from it. According to a Yoruba proverb, for instance, $a^{\prime} a^{\prime} b o$ o 'ro ' la 'a' so fơ molu' a 'bi', to' ba’ de inu' re ' $a^{\prime}$ ' dodidi (half a word is sufficient for the wise; when it gets to his thought process, it becomes whole).

A proverb is open to different interpretations, depending on the context and the sagacity of the user and audience. The person on whom the task of decoding falls, therefore, needs to probe beyond the surface of the proverb as stated, into the dark recesses of the "unsaid", using the context as a guide.

\section{Of African drama and the proverbial}

Drama, like other genres of literature, has explored the profundity of thought and verbal dexterity that a proverb offers in dialogue. Though the notion of drama in Africa embraces traditional rituals and festivals as well as the folk theatre practice of Hubert Ogunde, Kola Ogunmola and Duro Ladipo of Nigeria $^{1}$ or the popular Dan Ge entertainment in Ivory Coast, our focus is the literary drama tradition which captures the works of Western educated playwrights who wrote for the arts theatre and mostly in a colonialist language, English language (Clark, 1981; Ogunbiyi, 1981; and Etherton; 1982). In this category are Ngugi wa Thiong'o, John Ruganda, Ama Ata Aidoo, Wole Soyinka, Ola Rotimi, Ahmed Yerima, Efua Sutherland, Dele Charley, Lewis Nkosi, Yaw Asare, Mohammed ben-Abdallah and Joe de Graft among others. One major challenge before these dramatists is that

\footnotetext{
${ }^{1}$ Take the case of the Yoruba popular travelling theatre for instance, because it performed in the language of its people, dialogue in their plays were always enriched with proverbs and other rhetorical resources of the people including chants, panegyric, incantation and so on. These resources were carried over into the home video tradition in Yoruba, a thriving segment of the movie industry in Nigeria. Though the instances of wise sayings in the movies are getting fewer and fewer with increasing emphasis on youth characters, love and urban experiences by film makers, proverb is not altogether eliminated. Sometimes, titles of films are generated from proverbs, while some characters use counterproverbs or anti-proverbs for rhetorical and thematic purposes. As the elders say: ki ' $i^{\prime} t a^{\prime} n$ ni nu' igba' osu 'n, ka' ma' ri' fi pa omo la' ra (however dry the camwood bowl is, there will still be some left to rub on the body of the baby).
} 
of language as they write their plays largely in English, an option for which Obi Wali foresees a grave consequence which he terms the "dead end of African Literature" (2007).

Apart from the use of legends, folktales, myths and history, the proverb is another vital element drawn from the cultural background of the dramatists. For instance, Ola Rotimi uses proverbs in indigenous languages (though translated into English) in his attempt to produce African plays written in English. This goal is shared by other playwrights whose works are studied in this paper. In their translation of proverbs into English, the playwrights strive for the level of profundity and oratorical appeal offered in their original form in indigenous languages.

This is true of Akan proverbs in Aidoo's Anowa, and Sutherland's Marriage of Anansewa; Yoruba proverbs in Soyinka's A Dance of the Forests; Rotimi's Kurunmi, Igbo proverbs in Zulu Sofola's Wedlock of the Gods, Urhobo proverbs in Eghagha's Death, Not a Redeemer, and so on. In this regard, the proverb confers some naturalness on characters and the spaces they inhabit.

As earlier indicated, African dramatists use proverbs to elicit certain emotional responses from characters on stage as well as from the audience. In this case, a proverb may be twisted, manipulated and reconfigured into counter-proverb, anti-proverb or post-proverbial to achieve the aimed artistic effect. One remembers instances in African drama, where certain characters linger for a long time in the mind of the audience on account of such characters' peculiar use of proverbs. An illustration is found in Oladejo Okediji's $R e^{\prime} r e^{\prime} R u^{\prime} n$, a play in Yoruba. The peculiar use of proverbs by Lawuwo ( $O^{\prime}$ we $L a^{\prime} w u^{\prime} w o$ ) in his moments of emotional turmoil, are significant, not only in the humour and entertainment provided by their incongruity, but also in the development of characterisation. These examples of what Mieder (2012: 154) will call "twisted wisdom" or "anti-proverbial proverbs" underscore the fall of the vibrant labour leader, Lawuwo, who is now weighed down by a possible insinuation of mismanagement of the workers' money in his custody. This is because he will not be in a position to produce the money on demand by the workers, since his wife, Morenike, has unwittingly gambled with the money. In his state of psychological disturbance, he strings together the beginning and ending units of two or three proverbs. The consequent absurdity is sure to arouse laughter in the audience and achieve some comic relief, but they are bound to pity him for his fall from grace to grass in the manner of Aristotelian heroes. 
On the surface, the splicing of proverbs looks bereft of meaning, but it is meaningful when one considers the way it depicts Lawuwo's eccentricity and his reversal of fortune. Here is one of Lawuwo's proverbs:

...Sé ìwò táà ń wàparò, aṣo rẹ 'ń po’ n koko, sùgbớn àlùkò kò paṣo èsí dà, pírí lolongo ó jí. Látàárọ àná. Òjò ló ké yelé pọ mágbàdo (92).

(As we look at the partridge, its feathers become brown more and more, but the woodcock never changes its last year's dress, as the robin wakes up, bubbling with energy. Since yesterday morning, the rain has crowded the pigeon together with corn).

The proverbs strung together by Lawuwo are stated below:

i. İwò táà ń wàparò, bíi ká fi dá 'lá, orí eye ni kò peye

(As we cast a furtive glance at the partridge with the intent of cooking it in okra soup, it is the bird's providence that spares its life).

ii. Àgùntàn kò paṣo èsí dà.

(The sheep has not changed its cloth of last year).

iii. pírí lolongo ó jí, a kî́ bá òkùnrùn eyẹ lórí ìté .

(the robin wakes up bubbling with energy; no one finds a sick

bird in the nest).

iv. Òjò ló ke’ yẹlé pọ mádìe.

(It is the rain that crowds pigeons together with chickens)

The oratorical effect of the distorted proverbs can also not be ignored. He reminds one of the eccentric Marquis in Beatrice Grimshaw's The Sorcerer's Stone.

In Femi Osofisan's Midnight Hotel, the Headmaster Alatise, a businessman, politician and an educationist is remarkable for his inexhaustible pool of quaint proverbs. He has a "suitable' proverb for every anxiety-generating situation after he losing the gubernatorial election along with his huge financial investment. Some of the proverbs are not the popularly accepted ones, but self-invented. In addition to losing the election, the new government confiscates his land and his school. He is consequently bankrupt, jobless, homeless and hungry along with his daughters. Alatise's proverbs in their anti-proverbial tone, become psychological fillip to mediate his existential anguish which later impels him toward suicide as the plot unfolds. The proverbs are drawn from Yoruba and English linguo-cultural background. However, they are either platitudinous in nature, like "All that glitters is not gold" (29) or simply distorted like "The spirit was willing, but 
Adeoti, G./Legon Journal of the Humanities Vol. 30.1 (2019)

not the neck" (63), rather than "the spirit indeed is willing, but the flesh is weak". This is a biblical saying found in Matthew 26:41.

Alatise prefaces his wise sayings with "Eti' ró $o$ ' o!" (Let all ears be attentive!). This prepares the audience for profundity expected of a proverb. But due to their flawed or platitudinous construction, the audience is let down in a way that reinforces the overall burlesque ambience of the play. For instance, ordinarily, he would not want to lodge in Midnight Hotel with his three daughters who are "evidently exhausted" from their travelling. However, they have to settle for that as the only option they have in the circumstances after much efforts made to locate it:

ALATISE: Girls, no complaint. At least we've found it now. Eti' ro' -o' !

As the proverb says, no expectant woman enters the labour room with a smiling face....(27). When the Girls complain that the hotel looks so seedy like a den of robbers, Alatise cautions them:

ALATISE: Don't be too hasty, girls. There is no art to know the mind's construction from the frown, as the proverb says. Eti' ro ró $^{\prime}$ ! (28).

This is a parody of a saying in William Shakespeare's Macbeth. King Duncan in his discussion with Banquo provides the epigram. The correct quotation is: "There's no art, to find the mind's construction in the face" Macbeth I: IV, II. 12-13.

Because all the rooms in the hotel are already occupied, Alatise resolves to stay in the only room left, with his daughters. In accepting the offer, Alatise says: "Right then. Eti" ro' -o'! A beggar has no shoes, as they say" (30). The popular saying is that "A beggar has no choice". But the distortion also makes meaning in its own way as "shoelessness" graphically paints the picture of destitution. Though they hesitate to lodge in the room because there is no light there due to long neglect of the faulty switch, he encourages the daughters to settle for the option in spite of the inconvenience: "Come, my girls. Nothing ventured, nothing great. Eti' ro' -o'! (31). The usual expression is "Nothing ventured, nothing gained".

To his surprise and satisfaction, he finds in the room items like comb, toothbrush, glass, soap and perfume. The discovery elicits from him another self-generated/created proverb: "Etí ró-ó! Happiness is a perfume, you must pour it first on yourself for others to appreciate" (44).

He intervenes in the quarrel between Àwe ró and her husband, Asibong. In his mannerism, he declares: "Eti' ro' $-o$ '! The way to paradise, says the proverb, is like the narrow hole of the ballot box" (59). This is a 
parody of the Biblical saying that narrow is the way that leads to salvation while the way to damnation is broad.

The manner of proverb usage in Re' ré $R u^{\prime} n$ and Midnight Hotel is remarkably different from the realistic mode of its exploration in the dialogue of selected plays examined in this paper.

In some contexts, proverbs can be employed to generate humour and liven up the somber atmosphere and intense emotion in the plot. One category of proverb that primarily generates humour in context of use is the obscene type (Amali, 2001). Each culture has a body of obscene proverbs, but they are seldom openly employed in stage or screen discourse by African dramatists though some contexts permit their free usage in human interactions. The reality in African theatrical experience is that sex organs are usually euphemised rather than being mentioned openly and freely.

The proverb encapsulates more meaning than what lies on the surface. The meaning underneath the surface is what is regarded here as the "unsaid. To better understand the expressly stated content of a literary work, attention needs to be paid to the implied or unstated. This paradoxical supposition provides inspiration for our examination of some proverbs deployed at critical moments by some characters in the selected plays.

Let us now draw some examples from the selected plays to illustrate how proverbs are used to address or capture the issues that define the African experience.

In Soyinka's Death and the King's Horseman, the proverb is one of the rhetorical strategies used to elicit the "threnodic essence", which is the central element of the play. According to the playwright in his prefatory comments, its essence lies in the celebration of transition among the people rather than in the futile attempt by a supercilious agency of colonialism to arrest a cultural practice of the "natives" considered by the colonialists to be "barbaric". Soyinka explains: "The confrontation in the play is largely metaphysical, contained in the human vehicle which is Elesin and the universe of the Yoruba mind - the world of the living, the dead and the unborn, and the numinous passage which links all: transition" (1988: 145). Three characters that belong to the generation of "elders" bear the burden of this thematic concern. They are Ele' sin Oba (the King's Horseman), Olóhùn Iyọ ' (Praise-singer) and İyálọ jà (Mother of the market). In the play, Elesin Oba speaks in proverbs, "the language of our elders", not easily grasped by the women.

Olóhùn Iyọ`and İyálọ jà too spice their speeches with appropriate 
Adeoti, G./Legon Journal of the Humanities Vol. 30.1 (2019)

proverbs as the illocutionary horse that elegantly bears home the kernel of their conversations.

When the play begins, the Alaafin of Oyo has just joined his ancestors. The Oyo kingdom is under British colonial administration. Among the rites of transition, he is to be joined in the other world by his horse and the horseman for continuous order and stability in the polity. Approaching the final moments of the rites, Elesin decides to take a new bride and "travel light", like a considerate voyager who "sheds off his excessive load, all that may benefit the living" (159). However, Elesin is interrupted in the final moment of crossing the gulf of transition by the agency of British colonialism, Mr. Pilkings, the District Officer, who uses his guards to arrest Elesin and detain him. Unsettled by the imminent doom that the disruption of the final rites is likely to bring, the people settle for an alternative. They find a willing replacement in the heir of Elesin, Olunde, who "could not bear to let honour fly out of doors for his family" (218) and he stops the drift into abyss with his life. He takes the place of his father by undergoing the rituals of passage for the Elesin. As Praise-singer puts it proverbially, "if there is a dearth of bats, the pigeon must serve us for the offering" (218).

Though the alternative provided by Olunde helps the community to regain its violated equilibrium, it is not without its cost which the proverb above by Praise-singer does not capture. "Bat" here refers to Elesin and "pigeon" refers to Olunde, the youth in a culture that prays for its sapling to replace a banana stem. Elesin is expected to die before his son, thus, the alternative is calamitous for Elesin's family, though it provides succour for the community. It accentuates Elesin's reversal of fortune (peripeteia). It is not surprising therefore, that Elesin finally strangles himself when he can no longer withstand the shameful consequences of his hedonism, delay and incarceration. The disruption in the order of things is stressed by Praisesinger as unfortunate products of colonial intrusion. In his words..."we know this is not the way of life. Our world is tumbling in the void of strangers, Elesin." (218).

The bond between Elesin and Praise-singer is explored in what Soyinka calls "the evocation of music from the abyss of transition." Speaking in proverb, poetry and riddle, they are bonded by figurative diction right from the beginning of the play. Praise-singer has to protest Elesin's fast pace of movement which gives the impression that Elesin wants to abandon and leave him behind in this proverbial expression: "What tryst is this the cockerel goes to keep with such haste that he must leave his tail behind?". 
Elesin is the Cockrel and Praise-singer its tail. Not satisfied with Elesin's answer, he responds: "Because the man approaches a brand new bride he forgets the long faithful mother of his children" (147). Describing this as the way of the world, the proverb prepares the audience for dynamic and transient nature of life which the play emphasises. The proverbial expression also comments on loyalty and trust in relationships. Both values are on trial in the conflict of the play.

Though Elesin is to betray his people in the end, he is not presented in that light when the play begins. Indeed, he is cast in the light of tragic heroes as a man of trust, honour and integrity. Honour is a core virtue among the people and Elesin commits himself to his "carrier" role. He looks forward to fulfilling his own aspect of the social contract at the appropriate moment without delay. He buttresses his assurance thus: "Where the storm pleases, and when, it drects the giants of the forest..." (153).

Elesin recognises the paradox of human existence. While he is described as "a man of enormous vitality" who speaks, dances and sings with that infectious enjoyment of life" (147), he knows that life is not as perfectly laid as the horizon. Life is defined by change and non-permanence of any position, whether of prosperity or penury. Elesin demonstrates this understanding when he says:

The world is not a constant honey-pot

Where I found little I made do with little.

Where there was plenty I gorged myself. (153)

Human beings should, therefore, prepare to adapt and respond to each situation suitably in order to live a meaningful life. It also stresses the importance of moderation and contentment. This philosophical approach to life marks Elesin out as a man of honour (omolu' wa 'bi'). He is concerned with the fate of others. To be selfish is to court disgrace from unexpected quarters like the man in the proverb that eats without leaving some crumbs in the plates for children who are expected to pack them:

What elder takes his tongue to his plate,

licks it clean of every crumb? He will encounter

silence when he calls on children to fulfill

the smallest errand! Life is honour.

It ends when honour ends. (154) 
Adeoti, G./Legon Journal of the Humanities Vol. 30.1 (2019)

The proverb has an element of foreshadowing and dramatic irony as Elesin turns out to be the elder who licks his plate clean of crumbs by taking a new bride and refusing to join Alaafin at the appropriate moment of transition. For this, he encounters the consequences of that act of indiscretion in the hands of Iyaloja and the people in Scene 5. In the first Scene, he is regarded as "father" by Iyaloja and treated with dignity by the people. But his honour slips into a septic tank of shame when he is helplessly manacled and confined to a cage like an animal.

IYALOJA: It is the death of war that kills the valiant,

Death of water is how the swimmer goes

It is the death of a market that kills the trader. (184)

Even if he is not conscious of it, the proverb about the elder who licks his plate clean of crumbs is very significant for his role as a tragic hero who will later suffer a reversal of fortune in the plot. According to Iyaloja, "what we have no intention of eating should not be held to the nose" (211). She refers here to the act of taking a new wife even when the bride is already bethrothed to a young man, as an act of eating and leaving nothing in the plates for children. Earlier, she warns Elesin against this when she says: "Eating the $a w u$ 'sa' nut is not so difficult as drinking water afterwards" (162). Awusa here is the wallnut.

The role of youths in the struggle for emancipation from colonialism is demonstrated in the encounter between the young girls in the market and Sergeant Amusa and other policemen who are the disruptive agents of colonialism. As the girls torment and humiliate the policemen out of the market, Iyaloja triumphantly remarks: "Well, our elders have said it: Dada may be weak, but he has a younger sibling who is truly fearless" (180). Dada refers to the women and African natives, while the girls are the fearless siblings. In a way, there is a conflation of colonial domination with patriarchal oppression in the security guards led by Amusa. They are agents of colonialism and they are all men. The girls are able to stand up to the forces of colonialism and patriarchy because they are educated. This points to Soyinka's interrogation of the role that Western education plays in the colony. For the people and Olunde, Western education opens the eye to imperfections of Western civilisation. Rather than subservience and inferiority complex, education should breed in the people, a critical and questioning mind. 
The transition rite is accompanied with solemn music, riddle and poetic chants to create the atmosphere of threnody. This process is marked with uncertainty and confusion as attested to by Elesin when he says: "the seven-way crossroads confuses only the stranger" (183). There is, however, a courageous affirmation of his readiness to plunge into the abyss of transition in the following:

...the elephant

trails no tethering rope; that king

is not yet crowned who will peg an elephant-

...The elephant deserves

Better than we say "I have 'I have caught

A glimpse of something". If we see the tamer

Of the forest let us say plainly, we have seen an elephant. (183)

Elesin presents himself as being determined and unstoppable. The assurance creates suspense in the audience as events turn out to be the opposite of a man of valour that the proverb wants to make out of Elesin. It also unwittingly reinforces the extent of his crash as a tragic hero because he is no longer the elephant intended in the proverb. The "tamer of elephant" is ironically being tamed in Pilkings cage, giving him a cowardly image. In essence, the proverbs employed by Soyinka have greater implications beyond what they overtly suggest.

Another playwright who holds much fascination for his use of proverbs is Ola Rotimi. He uses proverbs as an expressive tool to convey the African experience on stage. In his usage of proverbs, Rotimi preserves sound, sense and symbols, in a way that represents their models in indigenous languages.

$\mathrm{Ku}^{\prime}$ runmi $^{\prime}$ is based on the Ijaye war in Yoruba history, focusing on the tragic ruin of Kurunmi, the Generalissimo of Yoruba army, Ijaye, his domain and his family. He raises objection to what he perceives as a violation of tradition - the installation of Adelu as Alaafin to succeed his father, Atiba, shortly after the transition of the latter. The tradition here is that the heir dies when the king dies. He does not succeed his father. Kurunmi's principled position in defence of tradition pitches him against the newly-installed king and the Ibadan forces who are under obligation to rise in defence of the Alaafin and the Oyo empire whenever under any threat of aggression. The support offered by the Egba and Europeans could not save Ijaye from disaster as the Ibadan people are able to overcome them 
following a spiritual error of judgement and tactical blunder: crossing River Ose, to go and meet a well-prepared and strategically located enemy army.

In the opening scene, Kurunmi creates a sense of urgency in resisting the perversion of tradition through a string of proverbial expressions:

The fire dies, its ashes

bear its memory with a shroud

of white fluff. (15)

He rapidly mobilises for war as evident in the message that he sends to the Emir of Ilorin, his friend. "Tell him that a man with fire in his hands welcome no delay" (28). When he is challenged by five of his soldiers for his "dictatorial and totalitarian" actions, he cautiously remarks that "When a rat laughs at a cat, there is a hole nearby..." (38). This means that the sudden confrontation put up by his surbodinates is not voluntary or by accident. Kurunmi believes that they must have been influenced by a powerful, but yet to be known principal force, which may be physical or spiritual.

Kurunmi objects to the installation of Adelu as Alaafin because: "Kurunmi will never prostrate himself to shoot a deer with a father one morning, and then squat with the son in the evening to shoot a goose !Never..." (21). He adds later that "When an Elder sees a mudskipper, he must not afterwards say it was a crocodile" (42). He sees doom awaiting Adelu and his supporters who are denigrating tradition. He uses the story of the tortoise that walks into disgrace due to lack of discretion:

when the tortoise

is heading for

a senselesss journey,

And you say to him:

'Brother tortoise,

brother tortoise,

when will you be

wise and come back

home?

The tortoise will say:

'Brother, not until

I have been disgraced

Not until I have been disgraced....(17) 
Close to this proverb in meaning is the fate of a cow that is about to be shipped to Europe and she is happy. "Ehn..let the cow go. When she gets to Whiteman's land, what will she become? C-o-r-n-e-d b-e-e-f!” (22).

Here are other proverbs with similar meaning:

"The bull-frog that rivals the size of the elephant will burst" (29).

"A goat gets wiser after an ear is dropped off" (32).

“... the young palm tree grows rapidly, and it is proud,

thinking, hoping that one day it will scratch the face of the sky" (35).

The bull frog above is the young Alaafin Adelu while Kurunmi is the elephant. He is confident that Alaafin and his allies who flout tradition will come to irreversible disaster in the end. Unfortunately, Rotimi does not hide the dramatic irony in the statement as the disaster of Ijaye and its Egba allies in the war shows that Kurunmi is the bull-frog while Alaafin and the Ibadan forces are the elephants in a reversal of fate. He captures the catastrophic defeat suffered by his forces in a response to the woman who is looking for her husband, a soldier: "Where elephants were being slaughtered by the thousand, how could a man take notice of the death of a house rat?" (84). It means that where great warriors are being killed in large numbers in the Ijaye's disatrous routing, it is difficult to account for soldiers of lower ranks. In the animal images, elephant stands for great warriors while house rat refers to men of lower ranks.

Somoye who is leading the Egba forces cautions that “...a man with grass on his buttocks must not forget himself when he goes to put out a neighbour's fire" (74). He is of the Egba allies fighting on the side of Kurunmi. He posits that they should not lose their own heads while trying to save those of Kurunmi and the Ijaye people.

After the defeat on the battle field, a body guard tries to put the blame of their routing on the Egba allies. Kurunmi disagrees and rather than blame, he prefers a sympathetic understanding of their plight. In his words, "When a one-legged man needs help, he must not say that the friend who carries him on the back stinks; even if that helper does stink" (83-84). The proverb is taken from the story of the tortoise and the black ant. The latter offers to help remould the carapace of the tortoise which is shattered and scattered after he falls on hard objects while jumping down from the sky. While on the journey with the rest of the birds, the tortoise abandons the birds and abuses their generosity due to his selfishness and greed. The black ant is doing the work of remoulding diligently, but he has to leave the task 
uncompleted when the tortoise remarks rudely three times that the black ant stinks.

In spite of the setback, however, Kurunmi's nobility is still palpable, as he rallies his people again for another attack against the enemy, this time in a self-reliant move. In a determined tone, he says: "It is the water that is spilt. The calabash is still unbroken. We fight on!" (89). His soldiers believe that they can still triumph over the Ibadan forces. They see their enemies as hawks in a metaphorical sense while they are the snail:

WARRIORS: The hawk!

The hawk yearns for

the taste of the snail.

But it forgets;

it forgets that the

shell of the snail

is no food for hawks.

The hawk will fail. (89)

And like the hawk, their enemies cannot do anything to harm them. They are sure of victory.

Besides, while Kurunmi deploys appropriate proverbs to justify his actions in defence of tradition, those proverbs are countered by Ibikunle and Ogunmola, the Ibadan allies who are vehemently opposed to the belligerent position of Kurunmi against the newly-installed Alaafin. Consequently, the proverb in this situation, sits on the two sides of the conflict. On the whole, proverbs not only contribute insight into the personality of Kurunmi, they also create the right mood, tone, and temper for the realisation of tragedy in the historical text.

The plays of Ama Ata Aidoo in equally significant measure, explore the use of proverbs to create a natural atmosphere of African conversation on stage. Though in Akan, like many other African cultures, the proverb is the pastime of elders, in Anowa which is here selected for illustration, proverb usage is not restricted to the elders. Old Man, Old Woman, (The-mouththat-eats-salt-and-pepper), Osam and Badua use proverbs, but Kofi and Anowa who represent the younger generation also allude to wise sayings in their conversations especially during the period of domestic tension.

Anowa is sourced in a folk tale. Its eponymous heroine is the typical intransigent young girl in folk narrative, who turns down almost every 
reasonable man that asks her hand in marriage, only to end up with a choice that will be widely considered a "bad or wrong choice". She lives with the consequences, usually unpalatable and tragic. Anowa refuses to be a priestess to a goddess as demanded. She also turns down every suitor, but turns up one day with a firm decision to marry Kofi Ako, a lazy man described by Badua, her mother, as "...this fool, this good-for-nothing cassava-man, this watery male of all watery males..." (15).

Against the strong opposition from Badua, she runs away from home in Yebi and elopes with Kofi Ako. They find prosperity, trading in slaves on the Highway and finally settle down in opulence in the Big House at Oguaa. But lack of a child; a defining factor in African marriage, stands between the couple and happiness. Anowa becomes anxious and hysterical while Kofi is angry at her strange ways. He wants to send her away. The marital turbulence continues until Kofi shoots himself and Anowa drowns to complete the tragedy.

Old Man and Old Woman, the wise ones with wide experience of life already hint at the beginning of the play that Anowa is a strange being whose behaviour is different from that of any "normal" girl. Stepping out of the norms as she does will only bring disaster on her. Old Woman warns: "Badua should tell her daughter that the sapling breaks with bending that will not grow straight" (8). Anowa refuses to grow straight as it is expected of normal girls in the culture; hence, she breaks like the sapling in the proverb as evident in her disastrous end. The same sense is conveyed in another proverb by Old Woman: "Badua should have told her daughter that the infant which tries its milk teeth on every bone and stone, grows up with nothing to eat dried meat with (21). The proverb implies that a child that refuses the counsel of elders often goes astray. The two proverbs prepare the audience for the tragedy at the end with their foreboding tone. Osam too is persuaded about the inevitability of disaster for a girl who behaves like Anowa when he says: "...the yam that will burn, shall burn, boiled or roasted" (13). Osam is not talking about yam and its manner of preparation for consumption. Rather, he is warning about what lies ahead and this reinforces Old Woman's view on the stubbornness of Anowa and the tragic consequences that such intransigent disposition will court in the end. Thus, African proverbs, apart from upholding social ethos, are useful in socialising young members of the society. In the hands of the dramatist, as evident in Anowa, they are strategic tools in conflict exposition, plot development and characterisation. 
In the conversation between Old Man and Old Woman, the playwright tries to present a balanced view of generational differences that pitch the youths against the older generation. While the Old Woman laments the improper orientation that produces disobedient children, Old Man thinks that rather than heaping the blame on the youths, it is better to consider all sides of the issue, including the responsibilities of parents. In his words, "the best way to sharpen a knife is not to whet one side of it only. And neither can you solve a riddle by considering only one end of it..." (20). After all, as Osam contends, "A crab never fathers a bird" ...(31). Children take after their parents. Riddle, like the proverb, has two sides both of which should always be taken into consideration in the task of interpretation. The side that is stated and that which is implied, imagined or suggested.

Reflecting on the uncommon loyalty, devotion, dependability and hard work of Anowa, Kofi remarks: “...they say that however good for licking the back of your hand is, it would never be like your palms" " (27). That Anowa is not like other girls is underscored by Kofi with this proverb. It registers her personality trait as a tragic heroine who has extra-ordinary qualities. Here is a wife who is so devoted to her husband like a sister. The positive value in her personality builds up empathy in the audience when she is undergoing a slide in fortune which culminates in her suicide. Proverb in this case reinforces the playwright's tragic epistemology.

Kofi enjoys the easy life and would not want Anowa to stress herself working. He employs slaves and domestic hands to free her of any chore, easy or stressful. She objects to this daily life of leisure and prefers to continue working with her hands. In her words, “...one stops wearing a hat only when the head has fallen off" (35).... one never stops wearing hats on a head which still stands on its shoulders" (53).

There is a clear indication that Aidoo indicts Africans who collaborated with whites to engage in slave trade, a practice that accounts for many centuries of Africans' misery. During the slave trade, millions of Africans were captured by fellow Africans, sold into slavery and shipped to Europe. These Africans, represented by Kofi, are the agents of slavery and colonialism. He has learnt the ways of the white people being in league with slave dealers and colonisers. By extension, he also represents postcolonial leaders who glory in material acquisition and exploitation of their citizens. He becomes prosperous from slavery, but the fruits of human exploitation

${ }^{2}$ This Akan proverb has a similar version in Yoruba as used in Ola Rotimi's Kurunmi. In the words of the play's hero: “... A foster-mother is not like the real mother. A foster-father cannot stand upright like the real father. Ten eyes, twenty eyes, countless eyes of the other person are not the same as a single eye of your own” (88). 
do not endure as his marriage to Anowa remains fruitless. In an aphoristic tone that has greater implications in the mind of the audience, Anowa hints at her tragic end. She declares: "...no man made a slave of his friend and came to much himself...it is wrong. It is evil" (30). She is conscious of the fact that they owe their sudden prosperity to the misery of fellow human beings. That informs another proverb from her: "The string of orphan beads might look better on the wrist of the leopard but it is the antelope who has lost his mother" (51). The leopard here refers to Kofi Ako who is enjoying his life of opulence attained through the sweat and blood of fellow Africans (metaphorised as the antelope) who are sold into slavery.

There is a gender dimension to Anowa that needs further attention. Women are supposed to be heard and not seen. Badua puts it sharply: "A good woman does not have a brain or a mouth" (33). Anowa crosses this gender boundary by acting freely in the choice of her husband. Badua represents the older generation of women who rather than challenge gender imbalance, reinforce it through acquiesence with tradition. A proverb is an expressive tool for articulting that acquiescence.

In his plays, Mohammed ben-Abdallah poignantly addresses the burning issues of power abuse, corruption, instability and nepotism that characterise politics and governance in many African countries in the postcolonial era. Even though his immediate target in his dramaturgy is Ghana, his country of origin, the issues raised in a play like The Trial of Mallam Ilya have far-reaching relevance to many countries in Africa after independence, from Cameroon to Uganda, from Burundi and Rwanda to Burkina Faso, Gambia and Nigeria.

In his preface to The Trial of Mallam Ilya, Yaw Asare, a Ghanaian playwright and critic, draws attention to indigenous literary elements explored by ben-Abdallah in his plays to give them traditional flavour. These include "a range of proverbs, imageries, and other local literary devices" (xiii).

The play begins on a note of confusion and disorder. A military coup has just taken place, led by Malwal. The new men of power are going after the key figures in the old regime and their perceived collaborators. One of them is Mallam Ilya, whose house is attacked and he is arrested. Ilya is a popular and influential Islamic religious leader who is expected by the people to use his closeness to power in successive regimes to speak truth to power. Unfortunately, he acquisces with oppressive and arbitrary conducts of the rulers through his audible silence. The polity suffers from his disappointing 
Adeoti, G./Legon Journal of the Humanities Vol. 30.1 (2019)

inaction. He is, therefore, seen as a traitor and he is put on trial by the new regime. According to Second Man, Ilya belongs to

A generation of ageless butterflies that have sucked from high

places from one generation of rulers to another with amazing agility.

Like a runner in the relay of time, he has sat in council after council

without break. But like a renegade and a traitor, he has failed to

let the lessons of history shine through him. (6)

His trial which constitutes the main action in the plot, provides revelations about how the nation of Angha (Ghana) arrives at its present state of corruption, chaos and instability, especially from the regime of the great old man, father of the nation, Mwake Kumrhan the Black (Kwame Nkrumah). It is a situation when, in the words of Ilya, "our deliverers become our executioners" (31).

The plot exposes the evil consequences of arbitrary rule - anarchy, corruption, and insecurity, instability and economic hardship. The play ends with the announcement of another military intervention which overthrows the regime that takes over at the beginning of the play, thus, giving the play's plot its cyclic structure. Apart from showing the futility of violent and arbitrary change of regime in addressing the challenges of development in post-independence Africa, ben-Abdallah also establishes the link between sychophancy and dictatorship. In the play. The latter thrives with the former as exemplified in the activities of "yes men" called "Elders of the Inner Council" - Bawa Samburu, El Fasi and Abdul Karim. They are the eyes of the regime and Kumrhan describes them as "the best brains". He tries to defend the choice of these Elders and his choice of Ilya too in his Inner circle of advisors when he says: "The child of today is the father of tomorrow. And as our elders say: "The child who keeps his hands clean, gets to eat with elders" (34). .

The praise song of the Court Crier is metaphorical and proverbial in content. "A fart may be a gush of wind but it can never feed a fire, it only smells" (18). There is an element of humour in the proverb as it lights up the prevailing atmosphere in the context in which it is used. However, it points to the grandeur of Kumrhan. He is depicted as a great man who cannot be overpowered by his enemies. The Crier reinforces the great personality of Kumrhan with another wise saying in his panegyric: "When was it said that the goat had enough courage to go and say good morning to the hyena?" (26). Rendered in the form of a rhetorical question, the proverb carries a tone of finality concernng the reality of invincibility that it expresses. 
Kumrhan has much hope in Ilya, the son of his teacher and mentor. He believes that if he is wise and clever, he has a bright prospect to rise into position of fame. Unfortunately, he falls short of this expectation as stated in the proverb: "The child of today is the father of tomorrow... the child who keeps his hands clean, gets to eat with elders" (34).

Apart from the huge dose of native wit and humour generated through the proverb, Court Crier's panegyric in the words of Asare, "recaptures the poetic ingenuity of the Ashanti Court Praise-singers" in a way that preserves this verbal art as it existed in its original performance in a local language and context" (xii). ben-Abdallah also uses his play to re-awaken attention in performance culture and ritual origin of African drama. Yaw Asare notes that he has what he calls a "near-obsessive conviction in the evocation of cultural and ritual authenticity, as a means of soliciting theatrical empathy". Cultural identification has always had a magnetic pull on even the urbane middle-to-top classes in Africa, and the playwright does not miss any opportunity to appropriate it for absolute effect.

\section{Conclusion}

From the foregoing, it has been shown that the proverb is a universal concept that manifests in most cultures of the world. No culture seems to lack the notion of the proverbial. It captures succinctly, concretely and imagistically, the experience of people over the years. It subsists on rhetorical deployment of words for thematic and aesthetic effects. Its literariness makes interpretation a corollary art of the proverb. Interpretation takes into cognizance, content and context. A proverb can apply to as many situations as possible; hence, its interpretation is open so long as there are correlating circumstances.

It is our contention that the proverb manifests in many discursive fora and performing arts. Drama, being the art that seeks to represent human experience most directly through mimesis, is a veritable forum for creators, communicators and critics to come to a greater understanding of the nature, role and aesthetic effects of proverb. This much is demonstrated in our analysis of five plays by five playwrights from Nigeria and Ghana as illustrative texts. These playwrights explore the communicative resources and potentials of proverbs in their drama.

In the textual analyses, it is evident that proverbs are used to build themes and characterisation. Therefore, the essay pays attention to the 
Adeoti, G./Legon Journal of the Humanities Vol. 30.1 (2019)

hidden but decipherable meanings of proverbs within and outside the textual context. In the acknowledged instances where they are deployed, proverbs lighten up and animate discussions. Where effectively deployed as one finds in the selected plays, there is much sense to harvest from the overtly stated component of a proverb as well as from its vast pool of the "unsaid". 


\section{References}

Akinyemi, A. (2007). The Use of Yoruba Proverbs in Akin Isola's Historical Drama, Madam Tinubu: Terror in Lagos. Proverbium 24: 17-37.

Aidoo, A. (1970). Anowa. London: Longman.

Amali, O. O. I. (2001). Linguistic and Semantic Aspects of Obscene Idoma Proverbs. Proverbium 18, 1-14.

Appiah-Adjei, D. (2014). Sankofa and Drama: A Study of Adinkra and Akan Clan Symbols in Modern Ghanaian Plays. (Doctoral Thesis), University of Ghana, Legon, Accra, Ghana.

Retrieved from http:ugspace.ug.edu.gh/bitstream/handle/12345678 on Thursday $16^{\text {th }}$ May, 2019.

ben-Abdallah, M. (2008). The Trial of Mallam Ilya. Accra: Sedco Publishing Limited.

Clark, J. P. (1981). Aspects of Nigerian Drama in Yemi Ogunbiyi (Ed.) Drama and Theatre In Nigeria: A Critical Source Book. Lagos: Nigeria Magazine, pp. 57-74.

Doyle, C. (2007). Observations in the Diachronic Study of Proverbs. Proverbium 18, 57-76.

Etherton M. (1982). The Development of African Drama. London: Hutchinson University Library.

Grimshaw, B. (1914). The Sorcererr's Stone. Philadelphia: John Winston. Mieder, W. (1985). Popular Views on the Proverb. Proverbium 2, 109-143. (1993).The wit of one, and the wisdom of many: General thoughts on the Nature of Proverb. Proverbs are Never out os Season : Popular wisdom in the modern age. Oxford: Oxford University Press, pp. 3-40.

------ (2012). Thinking Outside the Box: Origin, Nature, and Meaning of Modern Anglo-American Proverbs. Proverbium 29, 137-198.

Ogbeide, V. (2013). The Palm oil with which Eghagha's Words In Death, Not a Redeemer is Eaten. International Journal of Innovative and Applied Research. 1.2, 17-25

Ogunbiyi, Y. (Ed.). (1981). Drama and Theatre in Nigeria: A Critical Source Book. Lagos: Nigeria Magazine.

Okediji, O. (1973). Rere Run. Ibadan: Onibonoje Press.

Osofisan, F. 1985). Midnight Hotel. Ibadan: Evans Brothers.

Rotimi, O. (!970). Kurunmi. Ibadan: University Press Limited. 
Adeoti, G./Legon Journal of the Humanities Vol. 30.1 (2019)

Sjaak van der G. (1996). The Elder and his Elbow: Twelve Interpretations of an Akan Proverb. Research in African Literatures, 27.3, 110-118.

Soyinka W. (1988). Death and the King's Horseman in Six Plays. Ibadan: Spectrum Books Limited, 143-219.

Wali, O. (2007). The Dead End of African Literature in Tejumola Olaniyan and Ato Quayson (Eds) African Literature : An Anthology of Criticism and Theory.Malden MA: Blackwell Publishing, pp. 281-284.

Yankah, K. (2012). The Proverb in the Context of Akan Rhetoric. New York: Diasporic Africa Press 